Al Maal : Journal of Islamic Economics and Banking

http://jurnal.umt.ac.id/index.php/jieb

E-ISSN : $\quad 2580-3816$

Vol : No 1 Vol 2 Bulan Januari Tahun 2020

Hlm : $130-143$

DOI $\quad$ : $10.31000 /$ almaal.v1i2.1897

\title{
Pengaruh Bauran Promosi Terhadap Keputusan Nasabah Dalam Memilih Produk Pembiayaan
}

\author{
Lilis Muhlisoh ${ }^{1 *}$, Kholil Nawawi², Suyud Arif ${ }^{3}$ \\ ${ }^{123}$ Program Studi Ekonomi Syariah, FAI Universitas Ibn Khaldun Bogor, Indonesia \\ *lilismhlisoh3980@gmail.com
}

\begin{abstract}
The purpose of this study was to determine the promotional strategy undertaken by SRB HIK Insan Cita and its influence on the customer's decision in choosing financing. This research uses quantitative methods that are descriptive in nature. Data sources used are primary and secondary data. The population used was 300 customers and solvin formula used to be 67 sample respondents. Data collection techniques used by researchers are using respondents (questionnaires) and interviews. The method of data analysis in this study uses simple linear regression analysis. Promotional mix variables consisting of advertising (advertising), personal selling (personal selling), sales promotion (seles promotion), publicity (publicity) by conducting at test shows each variable has a significant influence on the purchase decision variable. Judging from the significant advertising variable 0.038, personal selling 0.001, selles promotion 0.039, and publicity 0.002, which means it is smaller than the significant level used that is 0.05. And can also be seen by $t$ count of 2,126, 3,366, 2,108, 3,248 which means $t$ count 0,224. From the results of the analysis examined that the promotion mix strategy significantly influences customer decisions.
\end{abstract}

Keywords: Promotion Mix; Purchasing Decisions; SRB HIK Insan Cita

\begin{abstract}
ABSTRAK
Tujuan dari penelitian ini adalah untuk mengetahui strategi promosi yang dilakukan oleh BPRS HIK Insan Cita dan pengaruhnya terhadap keputusan nasabah dalam memilih melakukan pembaiayaan. Penelittian ini menggunakan metode kuantitatif yang bersifat deskriptif analisis. Sumber data yang di gunakan adalah data primer dan sekunder. Populasi yang di gunakan yaitu 300 nasabah dan di gunakan rumus solvin menjadi 67 sempel responden. Teknik pengambilan data yg digunakan oleh peneliti adalah menggunakan responden (kuesioner) dan wawancara. Metode analisis data dalam penelitian ini menggunakan analisis regresi linear sederhana. Variabel bauran promosi yang terdiri dari periklanan (advertising), penjualan pribadi (personal selling), promosi penjualan (seles promotion), publisitas (publicity) dengan melakuakan uji $t$ menunjukan masing-masing variabel memiliki pengaruh yang signifikan terhadap variabel keputusan pembelian. Dilihat dari signifikan variabel periklanan (advertising) 0,038, penjualan pribadi (personal selling) 0,001, promosi penjualan (selles promotion) 0,039, dan publisitas (publicity) 0,002, yang berarti lebih kecil dari tingkat signifikan yang digunakan yaitu 0,05. Dan dapat dilihat juga dengan thitung sebesar 2.126, 3,366, 2,108, 3,248 yang berarti thitung 0,224. Dari hasil analisa yang diteliti bahwa strategi bauran promosi secara signifikan berpengaruh terhadap keputusan nasabah.
\end{abstract}

Kata kunci : Bauran Promosi; Keputusan Pembelian; BPRS HIK Insan Cita 


\section{Pendahuluan}

Bank Pembiayaan Rakyat Syariah (BPRS) adalah bank syariah yang dalam kegiatannya tidak memberikan jasa dalam lalu lintas pembayaran. BPRS berfungsi sebagai pelaksana sebagian fungsi bank umum, tetapi ditingkat regional dengan berlandaskan kepada prinsip syariah. Pada prinsip konvensional dikenal dengan Bank Perkreditan Rakyat. Bank Pembiayaan Rakyat Syariah merupakan bank yang khusus melayani masyarakat kecil dikecamatan dan di perdesaan. Jenis produk yang ditawarkan oleh Bank Pembiayaan Rakyat Syariah relatif sempit jika dibandingkan dengan bank umum, bahkan ada beberapa jenis jasa bank yang tidak boleh diselenggerakan oleh Bank Pembiayaan Rakyat Syariah, Seperti pembukaan rekening giro, dan ikut kliring. (Andri Soemitra ( 2018 : 44) Undang-Undang Nomor 21 Tahun 2008 tentang perbankan syariah mendefinisikan bahwa Bank Perkreditan Rakyat Syariah sebagai Bank Pembiayaan Rakyat Syariah. Ahmad Ifham (2013 : 149)

Pemasaran dalam tinjauan syariah menyandarkan pedoman etikanya pada nilainilai islami yang terdapat dalam Al-Quran dan Hadits. Promosi dalam tinjauan syariah harus sesuai dengan sharia Compliance yang mereflesikan kebenaran, kadilan dan kejujuran kepada masyarakat. Segala informasi yang terkait dengan produk harus diberitahukan secara transparan dan terbuka sehingga tidak ada potensi unsur penipuandan kecurangan dalam melakukan promosi, promosi yang tidak sesuai dengan kualitas atau kompensasi, contohnya promosi yang menampilkan imajinasi yang terlalu tinggi bagi konsumennya karena termasuk dalam praktik penipuan dan kebohongan. Untuk itu promosi yang semacam tersebut sangat dilarang dalam islam. Kartajaya dan Sula $(2008: 178)$

Amrin Abdullah (2017:64) Promosi dalam ekonomi syariah harus memperhatikan nilai-nilai kejujuran dan menjauhi penipuan. Media atau sarana dan metode yang digunakan harus sesuai dengan syariah. Strategi promosi tidak dapat diabaikan, produk yang memiliki keunggulan, kualitas, harga yang murah dan bermanfaat pun tidak mudah laku jika strategi promosi tidak dimainkan dengan baik. Strategi promosi dapat membantu posisi perusahaan dipasar, mempertahankan dan bahkan meningkatkan brand name yang bahkan sudah mendapat tempat di hati pelanggan. Bauran promosi merupakan suatu instrumen pemasaran yang cukup populer dibandingkan instrumen lainnya dan berpengaruh terhadap keputusan nasabah memilih pembiayaan di BPRS HIK Insan Cita.

Kaeng (2014), meneliti tentang pengaruh bauran promosi terhadap keputusan pembelian. Hasil penelitian menunjukkan secara simultan periklanan, promosi penjualan, pemasaran langsung, penjualan pribadi dan hubungan masyarakat berpengaruh positif dan simultan terhadap keputusan pembelian. Secara parsial periklanan, promosi penjualan, pemasaran langsung, penjualan pribadi dan hubungan masyarakat berpengaruh terhadap keputusan pembelian.

Khansa Irem, Pirzada Sami Ullah Sabri dan Zahra Amjad (2015) yang berjudul Sport Sponsorship As A Promotional Tool: An Exploratory Study In The Context Of Banking Sector Of Pakistan. Menemukan bahwa sponsor alat promosi olahraga adalah media yang paling menguntungkan dari promosi hari ini karena hampir semua nasabah menganggap Merek pada aktivasi tanah di mana sponsor dapat langsung berinteraksi dengan target audiens. Selain itu, hasil juga menunjukkan bahwa bank-bank tidak memiliki alat khusus untuk mengukur efektivitas sponsor olahraga. Penelitian ini bermanfaat untuk manajer untuk mengambil wawasan praktis yang bagaimana 
mengintegrasikan strategi sponsor olahraga dengan perusahaan secara keseluruhan bauran pemasaran. Penelitian ini menjadi kekuatan pendorong untuk memahami perhatian manajer untuk mengembangkan alat mekanisme untuk mengukur efektivitas sponsor olahraga. Adapun penelitian ini adalah untuk mengetahui bagaimana pengaruh promosi terhadap keputusan nasabah dalam memilih pembiayaan di BPRS Harta Insan Karimah Insan Cita Bogor.

\section{KAJIAN LITERATUR Pemasaran}

Definisi pemasaran menurut American Marketing Association (AMA) menurut Kotler \& Keller (2008:5) pemasaran adalah suatu fungsi organisasi dan serangkaian proses untuk menciptakan, mengkomunikasikan, dan memberikan nilai kepada pelanggan dan untuk mengelola hubungan pelanggan dengan cara yang menguntungkan organisasi dan pemangku kepentingan.

Sedangkan definisi pemasaran syariah menurut Firdaus Zaelani (2017: 268 ) Pemasaran syariah merupakan suatu proses bisnis yang seluruh prosesnya menerapkan nilai-nilai islam. Suatu cara dalam memasarkan suatu bisnis yang mengedepankan nilainilai yang mengagungkan keadilan dan kejujuran. Dengan prinsip islami, seluruh proses tidak boleh ada yang bertentangan dengan prinsip Islam.

\section{Strategi Promosi}

Lamb, Hair, dan McDaniel (2001:146) mendefinisikan Strategi promosi adalah rencana untuk penggunaan yang optimal dari elemen-elemen promosi: periklanan, hubungan masyarakat, penjualan pribadi dan promosi penjualan. Strategi promosi menurut Moekijat (2000 : 443) menyatakan strategi promosi adalah kegiatan perusahaan untuk mendorong penjualan dengan mengarahkan komunikasi-komunikasi yang meyakinkan kepada para pembeli. Dari defenisi diatas dapat dilihat bahwa strategi promosi merupakan kegiatan yang direncanakan dengan maksud membujuk, merangsang konsumen agar mau membeli produk perusahaan sehingga tujuan untuk meningkatkan penjualan diharapkan dapat tercapai.

Promosi dalam perspektif syariah merupakan suatu upaya penyampaian informasi yang benar terhadap produk barang atau jasa kepada calon konsumen atau pelanggan. Berkaitan dengan hal itu maka ajaran Islam sangat menekankan agar menghindari unsur penipuan atau memberikan informasi yang tidak benar bagi para calon konsumen atau pelanggan.

\section{Bauran Promosi}

Bauran promosi menurut Kismono (2011:396) adalah cara yang di tempuh oleh perusahaan dalam usaha memberikan informasi tentang produk atau jasa perusahaan, untuk mempengaruhi konsumen potensial melalukan pembelian, dan membuat konsumen tetap ingat atau setia kepada produk yang ditawarkan perusahaan. Setiap perusahaan akan berbeda-beda dalam merancang bauran promosinya tergantung pada tujuan perusahaan, strategi promosi, karakteristik produk dan karakteristik pasar sasarannya.

Menurut J. Stanton, bauran promosi (promotion mix) adalah kombinasi strategi yang paling baik dari variabel-variabel periklanan (advertising), penjualan pribadi 
(personal selling), dan alat promosi yang lain, yang kesemuanya direncanakan untuk mencapai tujuan program penjualan dari suatu perusahaan.

\section{Periklanan}

Iklan adalah berita pesan yang bertujuan untuk mendorong, membujuk kepada masyarakat tentang barang dan jasa yang ditawarkan. Periklanan adalah suatu komunikasi massa dan dibayar untuk menarik kesadaran, menanam informasi, mengembangkan sikap atau mengharapkan adanya suatu tindakan yang menguntungkan bagi pengiklan.

\section{Penjualan Pribadi}

Penjualan personal (personal selling) adalah komunikasi langsung (tatap muka) antara penjual dan calon konsumen untuk memperkenalkan suatu produk kepada calon konsumen terhadap produk sehingga mereka kemudian akan mencoba membelinya. Personal selling dapat mengambil berbagai bentuk, antara lain kunjungan wakil bisnis ke tempat pembeli (sales person), pelayanan penjualan ditoko eceran, dan sebagainya. Sarfilianty Anggiani ( 2019:150)

\section{Promosi Penjualan}

Sales promotion dalam perspektif Islam dianjurkan agar selalu memenuhi akad dan janji serta kesepakatan-kesepakatan diantara dua belah pihak (penjual \& pembeli). Hal ini sesuai dengan firman SWT dalam QS. Al-Maidah (5): 1.

Promosi penjualan dilakukan untuk menarik nasabah agar segera membeli setiap produk atau jasa yang ditawarkan. Tentu saja agar nasabah tertarik untuk membeli, maka perlu dibuatkan promosi penjualan yang semenarik mungkin.

\section{Publisitas}

Promosi yang keempat adalah pubilitas. Pubilitas merupakan kegiatan promosi untuk memancing nasabah melalui kegiatan seperti pameran, bakti social, serta kegiatan lainnya. Kegiatan publisitas dapat meningkatkan pamor bank dimata nasabahnya. Oleh karena itu publisitas perlu diperbanyak lagi. Kasmir (2010:156)

\section{Keputusan Pembelian}

Keputusan pembelian adalah suatu proses pengambilan keputusan akan pembelian yang mencakup penentuan apa yang akan dibeli atau tidak melakukan pembelian dan keputusan itu diperoleh dari kegiatan-kegiatan sebelumnya (Assauri, 2004:141).

Menurut Kotler dan Armstrong (2012:157), "Consumer buyer behavior refers to the buying behavior of final consumers, individuals and households that buy goods and services for personal consumption", pengertian tersebut dapat diartikan bahwa perilaku keputusan pembelian mengacu pada perilaku pembelian akhir dari konsumen, baik individual, maupun rumah tangga yang membeli barang dan jasa untuk konsumsi pribadi.

\section{Pembiayaan}

Menurut muhammad (2018 : 182) pembiayaan atau financing ialah pendanaan yang diberikan oleh suatu pihak kepada pihak lain untuk mendukung investasi yang telah 
direncanakan, baik dilakukan sendiri maupun lembaga. Dengan kata lain, pembiayaan adlah pendanaan yang dikeluarkan untuk mendukung investasi yang telah direncanakan.

\section{Metode Penelitian}

Jenis Penelitian

Dalam penelitian ini peneliti menggunakan metode pendekatan kuantitatif. Penelitian kuantitatif adalah metode penelitian yang berlandaskan pada filsafat positivisme digunakan untuk meneliti pada populasi atau sempel penelitian. Analisis data bersifat kuantitatif/statistic dengan tujuan untuk menguji hipotesis yang telah ditetapkan, metode ini disebut kuantitatif karena data penelitian berupa angka-angka dan analisis menggunakan statistik (Sugiyono : 2014).

\section{Populasi dan sempel}

Sugiyono (2012) menyatakan bahwa populasi adalah wilayah generalisasi yang terdiri atasobyek/subyek yang mempunyai kualitas dan karakteristik tertentu yang ditetapkan oleh penelitiuntuk dipelajari dan kemudian ditarik kesimpulannya. Populasi yang diambil dalam penelitianini adalah nasabah yang melakukan pembelian pada aaBPRS HIK Insan Cita pada bulan Januari-Agustus 2019 dengan total 300 nasabah.

Pengambilan Sempel dalam penelitian Ini menggunakan rumus Slovin.

$$
\frac{\mathrm{n}=\mathrm{N}}{1+\mathrm{N}^{2}} \quad \mathrm{n}=300 \quad \mathrm{n}=67 \text { Sempel }
$$

Keterangan:

$\mathrm{n}$ : jumlah sempel

$\mathrm{N}$ : jumlah populasi

E : Persen kelonggaran ketidaktelitian karena kesalahan pengambilan sampel yang masih dapat diterorir atau diinginkan.

\section{Teknik Pengambilan Data}

Menurut Sugiyono (2010:199) Kuesioner merupakan teknik pengumpulan data yang dilakukan dengan cara memberi seperangkat pertanyaan atau pernyataan tertulis kepada responden untuk dijawabnya.

Wawancara dilakukan peneliti dengan pihak manejemen BPRS Insan Cita Cabang Parung Bogor, untuk mengumpulkan informasi mengenai variabel yang diteliti yakni periklanan, penjualan personal, promosi penjualan, dan publisitas, terhadap keputusan nasabah melakukan pembiayaan.

\section{Definisi Operasional dan Pengukuran Variabel Penelitian}

\section{Tabel 1 Definisi Oprasional Variabel}

\begin{tabular}{|c|c|c|c|}
\hline Variabel & Sub Variabel & Definisi & Indikator Variabel \\
\hline $\begin{array}{l}\text { Bauran } \\
\text { Promosi }\end{array}$ & & $\begin{array}{lr}\text { Menurut } & \text { Achyar } \\
\text { Eldine } & (2013: 218)\end{array}$ & $\begin{array}{l}\text { Media cetak (koran, majalah), } \\
\text { Media siaran (Radio, Televisi) }\end{array}$ \\
\hline
\end{tabular}




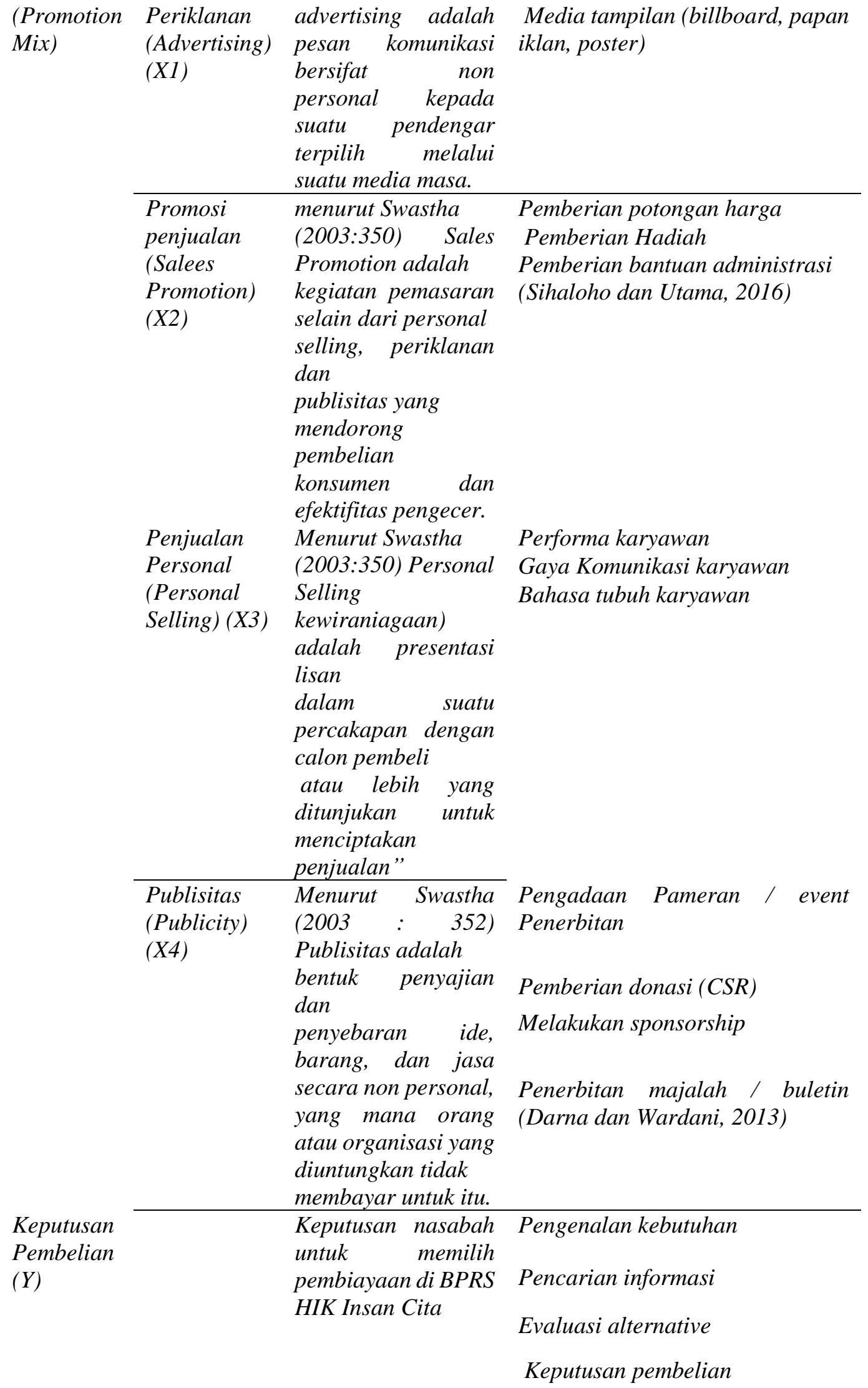




\section{HaSil dan PEMBahasan Sejarah Singkat BPRS HIK Insan Cita}

Pada mulanya PT. BPRS Harta Insan Cita didirikan oleh beberapa tokoh-tokoh ekonomi syariah dengan semangat asas syariah guna menyentuh sektor riil secara langsung yang pada saat itu Bank Umum Syariah (BUS) pada tahun 1998. Demi menjaga kinerja dan memperbaiki manajemen BPRS maka dilakukan akuisisi oleh holding company PT. INDUK Harta Insan Karimah (HIK). Di mana tujuan dari HIK Group ini adalah untuk mengembangkan BPRS HIK Group di Indonesia (nationwide) dengan visinya yaitu "Menuju Natio-Wide Sharia Micro Banking. Sehingga, konsekuensi akuisisi ini mengubah secara besar-besaran dari manajemen hingga nama BPRS Insan Cita menjadi PT. BPRS HIK Insan Cita.

\section{Visi Misi BPRS HIK Insan Cita}

Visi BPRS HIK Insan Cita ialah "Menjadi Bank Syariah yang unggul dan terpercaya". BPRS HIK Insan Cita memiliki motto "Maju Bersama dalam Usaha sesuai Syariah". Sedangkan misinya ialah sebagai berikut:

- Menjalankan usaha perbankan yang sehat dan amanah.

- Memberikan pelayanan yang terbaik dan Islami.

- Berperan aktif dalam pengembangan dunia usaha dan meningkatkan kesejahteraan masyarakat.

- Meningkatkan kesejahteraan pemegang saham, pengurus, dan karyawan.

- Menjalankan misi dakwah yang rahmatan lil alamin

\section{Data Responden}

Responden penelitian akan diuraikan secara deskriptif dan dibantu dengan penyajian dalam bentuk tabel dari jumlah responden dengan dibagi kedalam bebrapa tabel yaitu jenis kelamin, kelompok usia dan pendidikan terakhir.

Tabel 2 Responden berdasarkan jenis kelamin

\begin{tabular}{llll} 
No & Jenis Kelamin & Jumlah & Persentase \\
\hline 1 & Laki-laki & 46 & $69 \%$ \\
2 & Perempuan & 21 & $31 \%$ \\
& Total & 67 & $100 \%$ \\
\hline
\end{tabular}

Berdasarkan tabel diatas, diketahui responden dalam penelitian ini didominasi oleh laki-laki dengan jumlah sebanyak 46 responden (69\%) dari total 46 responden yang ditetapkan, dan sisanya sebanyak 21 responden (31\%) adalah perempuan.

Tabel 3 Responden berdasarkan usia

\begin{tabular}{llll} 
No & Umur & Jumlah & Persentase \\
\hline 1 & $20-30$ Tahun & 13 & $19 \%$
\end{tabular}




\begin{tabular}{llll}
2 & $31-40$ Tahun & 28 & $42 \%$ \\
3 & $41-50$ Tahun & 20 & $30 \%$ \\
4 & 50-60 Tahun & 6 & $9 \%$ \\
& Total & 67 & $100 \%$ \\
\hline
\end{tabular}

Berdasarkan tabel diatas, diketahui usia responden terbanyak adalah mereka yang berada pada usia 31-40 tahun, yaitu sebanyak 28 responden (42\%), kemudian 41-50 tahun sebanyak 20 responden (30\%), usia 20-30 tahun sebanyak 13 responden (19\%), dan 5060 tahun sebanyak 6 responden.

Tabel 4 Responden Berdasarkan Pendidikan terakhir

\begin{tabular}{llll} 
No & Pendidikan Terakhir & Jumlah & Persentase \\
\hline 1 & SD & 5 & $7 \%$ \\
2 & SMP & 12 & $18 \%$ \\
3 & SMA & 25 & $37 \%$ \\
4 & D3 & 10 & $15 \%$ \\
5 & S1 & 15 & $22 \%$ \\
6 & S2 & - & - \\
7 & S3 & - & - \\
& Total & 67 & $100 \%$ \\
\hline
\end{tabular}

Berdasarkan tabel di atas, diketahui pendidikan terakhir responden terbanyak adalah mereka yang pendidikan terakhirnya SMA dengan jumlah 25 responden (37\%), S1 sebanyak 15 responden (22\%), SMP sebanyak 12 responden (18\%), Diploma (D3) sebanyak 10 responden (15\%), dan SD sebanyak 5 responden $(7 \%)$.

\section{Hasil Uji Validitas dan Uji Reliabilitas}

Uji validitas digunakan untuk mengukur ketepatan suatu item dalam kuesioner atau sekala yang akan diukur. Uji validitas dilakukan dengan membandingkan $\mathrm{r}$ hitung ( nilai Corrected Item - Total Correlation pada output Cronbach Alpha) dengan nilai $r$ tabel untuk deagree of freedom $(\mathrm{df})=\mathrm{n}-\mathrm{k}$, dalam hal ini (n) merupakan jumlah sampel dari (k) merupakan jumlah variabel independen.

Tabel 5 Data Uji Validitas

\begin{tabular}{|c|c|c|c|c|}
\hline & Variabel & $R$ Hitung & $R$ Tabel $(5 \%)$ & Keterangan \\
\hline & & 0,574 & 0,224 & Valid \\
\hline & & 0,373 & 0,224 & Valid \\
\hline & Periklanan & 0,522 & 0,224 & Valid \\
\hline & & 0.632 & 0,224 & Valid \\
\hline & & 0,671 & 0,224 & Valid \\
\hline & & 0,258 & 0,224 & Valid \\
\hline & Penjualan & 0,527 & 0,224 & Valid \\
\hline & Pribadi & 0,468 & 0,224 & Valid \\
\hline Bauran Promosi & & 0,615 & 0,224 & Valid \\
\hline & & 0,370 & 0,224 & Valid \\
\hline & & 0,609 & 0,224 & Valid \\
\hline & Promosi & 0,599 & 0,224 & Valid \\
\hline & Penjualan & 0,630 & 0,224 & Valid \\
\hline & & 0,552 & 0,224 & Valid \\
\hline & & 0,671 & 0,224 & Valid \\
\hline
\end{tabular}




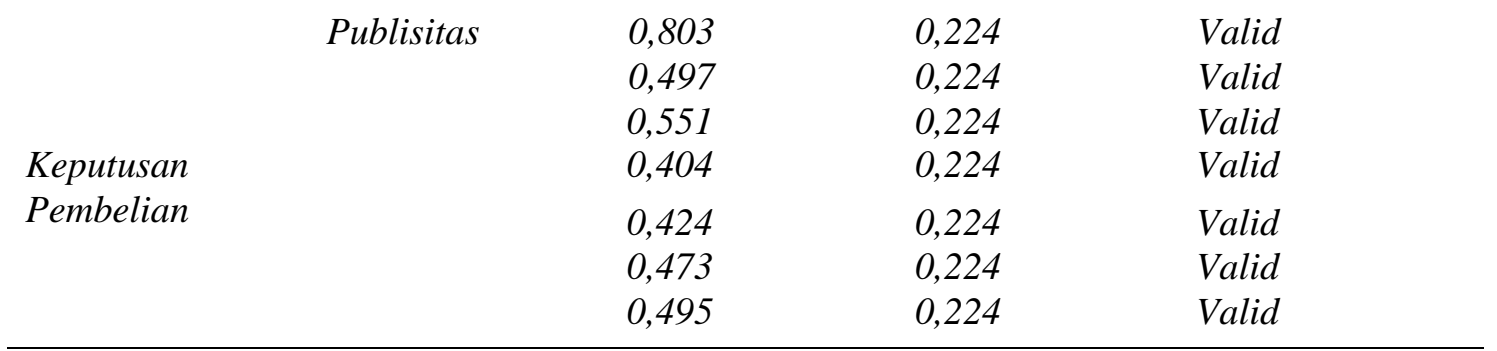

Dari tabel diatas, diketahui variabel bauran promosi yang terdiri dari periklanan, penjualan pribadi, promosi penjualan, publisitas dan keputusan pembelian memiliki kriteria yang valid untuk semua item pernyataan berdasarkan dengan $r$ hitung lebih besar dari $r$ tabel $>0,224$. Hal tersebut menunjukan bahwa indikator dari variabel bauran promosi dan keputusan pembelian dinyatan valid sebagai alat ukur uji validitas penelitian.

\section{Uji Reliabilitas}

Uji realiabilitas digunakan untuk mengukur suatu kuesioner yang merupakan indicator dari variabel. Suatu variabel dapat dikatakan reliable jika memberikan nilai cronbach alpha >0.6. Pengukuran koefisien cronbach alpha dilakukan dengan menggunakan SPSS versi 23. Berikut adalah hasil dari variabel bauran promosi terhadap keputusan pembelian.

\section{Tabel 6 Hasil Uji Realiabilitas}

\begin{tabular}{lllll} 
No & Variabel & $\begin{array}{l}\text { Cronbach } \\
\text { Alpha }\end{array}$ & $\begin{array}{l}\text { Cronbach } \\
\text { Alpha yang di } \\
\text { isyaratkan }\end{array}$ & Keterangan \\
\hline 1 & Periklanan & 0.699 & $>60 \%$ & Reliable \\
2 & Penjualan Pribadi & 0.616 & $>60 \%$ & Reliable \\
3 & Promosi Penjualan & 0.717 & $>60 \%$ & Reliable \\
4 & Publisitas & 0.750 & $>60 \%$ & Reliable \\
5 & Keputusan Pembelian & 0.621 & $>60 \%$ & Reliable \\
\hline
\end{tabular}

Sumber : data diolah dengan SPSS 23, 2019

Berdasarkan data diatas, dapat dilihat bahwa Cronbach Alpha $>60$ yaitu $(0,654),(0,719),(0,667),(0,620)>0,60$ untuk variabel bauran promosi dan $(0,630)>0,60$ untuk variabel keputusan pembelian. Maka setiap variabel yang diujikan adalah reliable.

\section{Uji Normalitas}

Uji normalitas adalah usaha untuk menentukan apakan data variabel yang kita miliki mendekati populasi distribusi normal atau tidakdata dikatakan terdistribusi normal jika memenuhi asumsi normalitas data yaitu, data menyebar disekitar garis diagonal, maka model regresi dikatakan tidak memenuhi asumsi normalitas. 


\section{Grafik 1 Hasil Uji Normalitas}

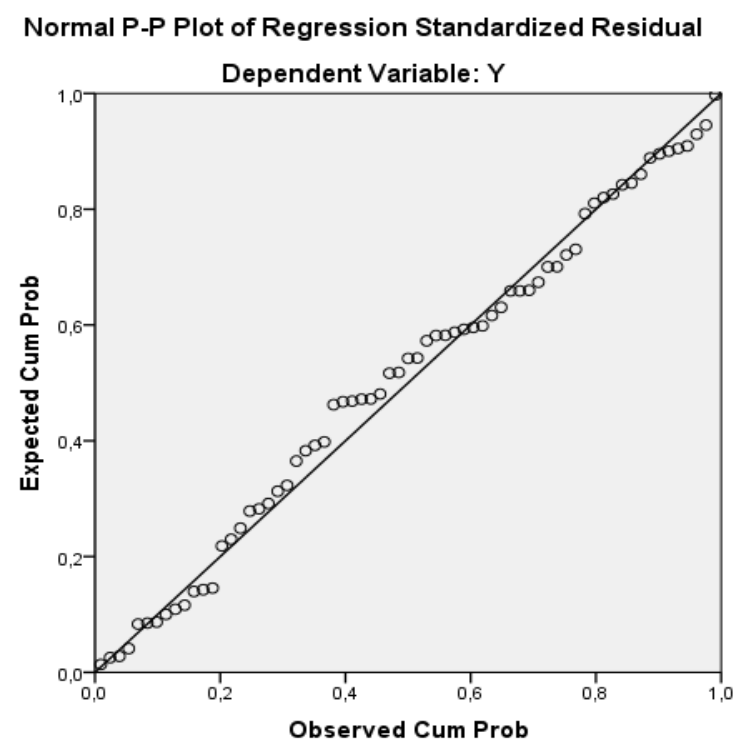

Sumber : data diolah dengan SPSS 23,2019

Berdasarkan hasil uji normalitas dengan menggunakan grafik normal probabilly plot menunjukan bahwa pola titik-titik pada grafik terlihat menyebar disekitar garis diagonal dan mengikuti arah garis diagonal, sehingga dapat disimpulkan bahwa data berdistribusi normal, maka model regresi yang digunakan dalam penelitian ini memenuhi asumsi normalitas.

\section{Uji Hipotesis}

\section{Uji T}

Uji statistik T pada dasarnya menunjukan seberapa jauh pengaruh suatu statistik independen secara individual dalam menerangkan variasi variabel terkait dependent.

Berikut ini hasil uji hipotesis (Uji statistik t) dalam penelitian bauran promosi periklanan (X1) penjualan personal(X2), promosi penjualan (X3), publisitas (X4) terhadap keputusan pembelian (Y).

Tabel 7 Hasil Uji Hipotesis (Uji statistik $t$ )

\section{Coefficientsa}

\begin{tabular}{|c|c|c|c|c|c|}
\hline \multirow{3}{*}{$\begin{array}{l}\text { Model } \\
\text { (Constant) }\end{array}$} & \multicolumn{2}{|c|}{ Unstandardized Coefficients } & $\begin{array}{l}\text { Standardized } \\
\text { Coefficients }\end{array}$ & \multirow{3}{*}{$\begin{array}{l}T \\
3517\end{array}$} & \multirow{3}{*}{$\begin{array}{l}\text { Sig. } \\
.001\end{array}$} \\
\hline & $\bar{B}$ & Std. Error & Beta & & \\
\hline & 15,890 & 4,518 & & & \\
\hline$X 1$ &, 275 &, 129 & ,226 & 2,126 & 038 \\
\hline$X 2$ &, 501 & 149 & 362 & 3,366 & 001 \\
\hline$X 3$ &,- 242 &, 115 &,- 227 & $-2,108$ & 039 \\
\hline$X 4$ &,- 370 &, 114 &,- 350 & $-3,248$ &, 002 \\
\hline
\end{tabular}

a. Dependent Variable: $Y$

Sumber : data diolah dengan SPSS 23,2019 
Diketahui bahwa thitung Periklanan (advertising) adalah 2,126, penjualan pribadi adalah 3,366, promosi penjualan adalah $-2,108$, dan publisitas adalah 3,248, sedangkan ttabel bisa dihitung a =0,05 karena digunakan hipotesis dua arah, ketika mencari tabel, nilai a dibagi dua menjadi 0,025 serta $\mathrm{df}=\mathrm{n}-2$, dimana $\mathrm{df}=67-2=65$, dan didapat nilai ttabel sebesar 0,224. Sehingga hasil yang di dapat thitung $>$ ttabel dimana $(2,126>0,224)$, $(3,336>0,224),(2,108>0,224),(3,248>0,224)$ dan nilai probabilitas signifikansi $(0,038$ $<0,05),(0,001<0,05),(0,039<0,05),(0,002<0,05)$. Maka dapat disimpulkan bahwa H0 ditolak dan Ha diterima. Hal ini berarti kualitas produk secara parsial berpengaruh signifikan terhadap proses keputusan nasabah. Bauran promosi periklanan (X1), penjualan pribadi (X2), promosi penjualan (X3), dan publisitas (X4)berpengaruh signifikan terhadap Proses Keputusan Nasabah (Y)

Periklanan (X1) terhadap Proses Keputusan Nasabah (Y)

H0: $\beta 1=0$; Tidak terdapat pengaruh yang signifikan antara periklanan (X1) terhadap Proses Keputusan Nasabah (Y).

Ha: $\beta 1 \neq 0$; Terdapat pengaruh yang signifikan antara periklanan(X1) terhadap Proses Keputusan Nasabah (Y).

Penjualan Pribadi (X2) terhadap Proses Keputusan Nasabah (Y)

H0: $\beta 1=0$; Tidak terdapat pengaruh yang signifikan antara Penjualan Pribadi (X2) terhadap Proses Keputusan Nasabah (Y).

Ha: $\beta 1 \neq 0$; Terdapat pengaruh yang signifikan antara Penjualan Pribadi (X2) terhadap Proses Keputusan Nasabah (Y).

Promosi Penjualan (X3) terhadap Proses Keputusan Nasabah (Y)

H0: $\beta 1=0$; Tidak terdapat pengaruh yang signifikan antara Promosi

Penjualan (X3) terhadap Proses Keputusan Nasabah (Y).

Ha: $\beta 1 \neq 0$; Terdapat pengaruh yang signifikan antara Promosi Penjualan (X3) terhadap Proses Keputusan Nasabah (Y).

Publisitas (X4) terhadap Proses Keputusan Nasabah (Y)

H0: $\beta 1=0$; Tidak terdapat pengaruh yang signifikan antara Publisitas (X4) terhadap Proses Keputusan Nasabah (Y).

Ha: $\beta 1 \neq 0$; Terdapat pengaruh yang signifikan antara Publisitas (X4) terhadap Proses Keputusan Nasabah (Y).

Uji F

Uji ini dilakukan dengan membandingkan antara nilai $\mathrm{f}$ hitung dan $\mathrm{f}$ tabel dengan menggunakan tingkat signifikan sebesar 5\%. Jika nilai f hitung > dari f tabel maka secara bersama-sama seluruh variabel independen mempengaruhi variabel dependen. Selain itu, dapat juga dengan melihat nilai probabilitas. Jika nilaiprobabilitas lebih kecil daripada 0,05 (untuk tingkat signifikan $=5 \%$ ), maka variabel independen secara besama-sama berpengaruh terhadap variabel dependen. Sedangkan jika nilai probabilitas lebih besar daripada 0,05 maka variabel independen secara serentak tidak berpengaruh terhadap variabel dependen. 
Tabel 8 Uji Statistik (Uji F)

\begin{tabular}{|c|c|c|c|c|c|}
\hline $\begin{array}{l}\text { ANOVA } \\
\text { Model }\end{array}$ & Sum of Squares & $D f$ & Mean Square & $F$ & Sig. \\
\hline Regression & 45,775 & 4 & 11,444 & 7,090 &, $000^{b}$ \\
\hline Residual & 100,075 & 62 & 1,614 & & \\
\hline Total & 145,851 & 66 & & & \\
\hline \multicolumn{6}{|c|}{ a. Dependent Variable: $Y$} \\
\hline b. Predictor & (Constant), X4, & $X 1, X$ & & & \\
\hline
\end{tabular}

Berdasarkan hasil uji Anova atau uji F menunjukkan bahwa data diatas didapatkan nilai fhitung 7,090 sedangkan $\mathrm{f}$ tabel dalam penelitian ini dimana df $1=\mathrm{k}-1$, dan df $2=$ $\mathrm{n}-\mathrm{k}$, dimana dalam penelitian ini jumlah variabel independen 4 dan variabel dependen 1 serta jumlah sampel penelitian ini sebanyak 67, sehingga df $1=5-1=4$ dan df $2=67$ $-5=62$, jadi, dapat dilihat ftabel pada penelitian ini 2,53, sehingga dapat disimpulkan 7,090 > 2,53 dan probabilitas signifikansi pada penelitian ini $0,000<0,05$, maka dapat disimpulkan H0 ditolak dan Ha diterima, bahwa keempat variabel periklanan (X1), penjualan pribadi (X2), promosi penjualan (X3), dan publisitas (X4) secara bersama-sama atau simultan berpengaruh terhadap proses keputusan nasabah.

Uji Determinasi $\mathrm{R}^{2}$

Untuk mengetahui determinasi variabel yang diteliti dalam penelitian ini dapat dilihat pada tabel berikut ini:

\section{Tabel 9 Uji Koefisien Determinasi (Adjust $R^{2}$ )}

Model Summary

\begin{tabular}{lllll} 
Model & $R$ & $R$ Square & $\begin{array}{l}\text { Adjusted } \\
\text { Square }\end{array}$ & $R$ \\
\hline 1 &, $560 a$ &, 314 &, 270 & 1,270
\end{tabular}

a. Predictors: (Constant), X4, X1, X3, X2

Sumber : diolah dengan SPSS 23, 2019

Dari tabel koefisien determinasi $\left(\mathrm{R}^{2}\right)$ diatas menunjukkan besarnya adjusted $R^{2}$ adalah 0,270 hal ini berarti $27,0 \%$ variabel dependent proses keputusan nasabah dapat dijelaskan oleh keempat variabel independen, yaitu periklanan, penjualan pribadi, promosi penjualan, dan publisitas. Sedangkan sisanya dipengaruhi atau dijelaskan oleh variabel lain yang tidak masuk dalam penelitian ini.

\section{KESIMPULAN}

Berdasarkan hasil analisis data terdapat hasil bahwa korelasi antara pengaruh bauran promosi periklanan, penjualan pribadi, promosi penjualan dan publisitas terhadap proses keputusan pembelian pada nasabah BPRS Insan Cita.

Strategi promosi yang dilakukan oleh BPRS HIK insan Cita telah mengikuti semua promosi yang terdiri dari periklanan (Advertising), penjualan pribadi (personal selling), promosi penjulan (selles promotion), dan publisitas (publicity) untuk menarik minat nasabah untuk melakukan pembiayaan di BPRS HIK Insan Cita.Variabel periklanan mempunyai pengaruh yang signifikan secara parsial terhadap proses 
keputusan nasabah (BPRS Insan Cita Cabang Parung Bogor). Pada saat uji statistik t dimana t hitung lebih besar dari pada t tabel yakni 2,259>0,244 dan nilai probabilitas signifikansi $0,027<0,05$. Variabel penjualan pribadi mempunyai pengaruh yang signifikan secara parsial terhadap proses keputusan nasabah (BPRS Insan Cita Cabang Parung). Pada saat uji statistik $t$ dimana $t$ hitung lebih besar dari pada $t$ tabel yakni 3,473 $>0,244$ dan nilai probabilitas signifikansi $0,001<0,05$. Variabel promosi penjualan mempunyai pengaruh yang signifikan secara parsial terhadap proses keputusan nasabah (BPRS Insan Cita Cabang Parung Bogor). Pada saat uji statistik t dimana t hitung lebih besar dari pada t tabel yakni -2,104 > 0,244 dan nilai probabilitas signifikansi 0,039< 0,05 . Variabel publisitas mempunyai pengaruh yang signifikan secara parsial terhadap proses keputusan nasabah (BPRS Insan Cita Cabang Parung Bogor). Pada saat uji statistik t dimana t hitung lebih besar dari pada t tabel yakni 3,401>0,244 dan nilai probabilitas signifikansi $0,001<0,05$. Variabel bauran promosi yang terdiri dari periklanan, penjualan pribadi, promosi penjualan , dan publisitas bersama-sama mempunyai pengaruh yang signifikan secara simultan terhadap proses keputusan nasabah (BPRS Insan Cita Cabang Parung bogor). Berdasarkan hasil uji Anova atau uji F didapatkan nilai f hitung 7,090 sedangkan $\mathrm{f}$ tabel dalam penelitian ini 2,53 sehingga dapat disimpulkan 7,090 > 2,53 dan probabilitas signifikansi pada penelitian ini $0,000<0,05$.

\section{REFERENSI}

Abdullah, Amrin. (2017). Strategi Pemasaran Syariah. Penerbit Grasinda: Jakarta.

Adi, Candra. (2018) Manajemen Agribisnis Perikanan. Penerbit UB Press: Malang.

Eldine,Achyar.(2013). Pengantar Bisnis Umum Dan Agri. Penerbit Direktorat Jenderal Perkebunan Kementrian Pertanian: Jakarta.

Huda, Hudari, Fahlevi. (2017) Pemasaran Syariah. Penerbit PT Kharisma Putra Utama: Depok 2017.

Ikatan Banker Indonesia (IBI). (2017). Strategi Sukses Bisnis Bank. Penerbit PT Gramedia Pustaka Utama : Jakarta

Ikatan Bankir Indonesia (IBI). (2018) Startegi Bisnis Bank Syariah. Penerbit PT Gramedia Pustaka: Jakarta 2018

Ikit, Zuhri. (2017) Akuntansi Penghimpunan Dana Bank Syariah. Penerbit Deepublish : Yogyakarta

Karsidi. (2018). Ibadah Dan Bisnis di BPR Syariah. Penerbit PT Gramedia: Jakarta. 2018.

Wangsawidjaja. (2012) Pembiayaan Bank Syariah. Penerbit PT Gramedia: Jakarta

Kasmir. (2010)Pemasaran Bank. Penerbit Perenada Media Group: Jakarta

Ismail, Muhammad dan Muhammad Karebet. (2008). Menggagas Bisnis Islam. Penerbit Gema Insani

Lasmi, Mia, Wardiyah. (2019) Pengantar Perbankan Syariah. Penerbit CV Pustaka Setia: Bandung

Muhammad, Syakhir Sula. (2004). Asuransi Syariah Life and Ganeral Konsep Dan System Oprasional. Penerbit Gema Insani Press: Jakarta

Muhammad Syafi'i Antonio. (2001). Bank Syariah Dari Teori Ke Praktik. Penerbit Gema Insani dan Tazkia Cendata: Jakarta 
Muhammad, Antonio Syafi'i. (2004). Asuransi Syariah ( Life and General) Konsep Dan Sistem Oprasional. Penerbit Gema Insani : Jakarta

Rananda, Iman, Cahya (Dalam kutipan Fitri Maisya 2018). Pengaruh Iklan dan Promosi PenjualanTerhadap Minat Masyarakat Bertransaksi Di Bank Syariah. Program Studi Perbankan Syariah. Universitas Islam Negeri Lampung

Rangkuti, Freddy. (2009). Strategi Promosi Yang Kreatif Dan Analisis Kasus Integrated Marketing Communication. Penerbit PT Gramedia Pustaka Utama : Jakarta

Rosyadi, Imron. (2017) Jaminan Kebendaan Berdasarkan Akad Syariah. Penerbit Prenadamedia Group : Depok.

Sharianews.com

Suryani, Tatik. (2017). Manajemen Pemasaran Strategik Bank Di Era Global Menciptakan Nilai Unggul Untuk Kepuasan Nasabah. Penerbit Prenadamedia Group : Jakarta

Suyatno, Thomas. Djuhaepah. Marala. (2010). kelembagaan perbankan. Penerbit PT. Gramedia Pustaka Utama: Jakarta.

Soemitra, Andri. (2018). Bank Lembaga Keuangan Syariah. Penerbit Perenada Media Group: Jakarta

Turmudi Muhammad (2015), Pembiayaan Griya Bank Syariah Mandiri Studi Kasus Pada Bank Syariah Mandiri Cabang Kendari, Jurnal Al-Izzah. Vol. 10 No. 1, Juli 2015 